\title{
Spartina Alterniflora Raised Soil Sulfide Content by Regulating Sulfur Cycle-Associated Bacteria in the Jiuduansha Wetland of China
}

Chiquan He

Shanghai University

Liyu Cheng

Shanghai University

Daoyuan Wang

Shanghai University

Zhenzhen Zhao ( $\square$ zhaozhen0828@126.com )

Shanghai University https://orcid.org/0000-0001-8268-2698

Zhengyu Wang

Shanghai University

Feifei Wang

Shanghai University

Xiaoxi Wang

Shanghai University

Pu Zhang

Shanghai University

Xueping Chen

Shanghai University

Xiaoyan Liu

Shanghai University

\section{Research Article}

Keywords: Spartina alterniflora, Scirpus mariqueter, bacterial composition, functional genes, sulfide

Posted Date: June 24th, 2021

DOl: https://doi.org/10.21203/rs.3.rs-614913/v1

License: (c) (i) This work is licensed under a Creative Commons Attribution 4.0 International License.

Read Full License 
Version of Record: A version of this preprint was published at Plant and Soil on September 18th, 2021. See the published version at https://doi.org/10.1007/s11104-021-05154-x. 


\section{Abstract}

Purpose The Spartina alterniflora invasion across the southeast coast in China significantly reduced vegetation diversity and generated associated ecological problems. Sulfur (S) is a vital nutrient, while sulfide is phytotoxic and the impact of $S$. alterniflora invasion on soil S cycle remains unclear. Therefore, this study aims to investigate the impacts of $S$. alterniflora invasion on the $S$ cycle and associated soil microbial communities.

Methods Both field investigation and lab-scale experiments were conducted, analyzing soil sulfide and sulfate contents, soil properties over four seasons in the Jiuduansha Wetland of Shanghai, China, the high-throughput sequencing of soil microbial communities, $\mathrm{S}$ cycle-related functional genes and seed germination experiments.

Results The contents of sulfide, soil organic carbon (SOC), and total nitrogen (TN) in the bulk soil of $S$. alterniflora invaded area were higher than those in the native species $S$. mariqueter habitat and bare mudflat soils. Spartina alterniflora invasion increased the abundance of the Nitrospiraceae and Desulfarculaceae families and reduced that of Hydrogenophilaceae. The relative abundance of the $S$ reduction functional genes $(d s r A+d s r B)$ in the soil was increased after $S$. alterniflora invasion, while that of the $S$ oxidation functional genes $(y e d Z+\operatorname{sox} Y)$ in the soil was reduced. Seed germination experiments with different sodium sulfide concentrations $\left(\mathrm{Na}_{2} \mathrm{~S}\right)$ revealed that the phytotoxicity of sulfide caused more lethal damage to $S$. mariqueter than to $S$. alterniflora.

Conclusion The S. alterniflora invasion significantly increased SOC and TN contents and reduced the abundance of sulfur-oxidizing functional genes, which led to the accumulation of soil sulfide.

\section{Introduction}

Plant invasion can dramatically reduce the biodiversity of the native ecosystem by dramatically reducing the abundance and survival rate of native species (Mack et al. 2000). It also generate ecosystem degradation by altering both soil nutrient cycling processes and hydrological parameters (Sanderson et al. 2001; Wang et al. 2020; Li et al. 2021). The Spartina alterniflora is an invasive plant in coastal wetlands of China across climate zones, which was introduced to China to reduce soil erosion in the 1990s (Chung et al. 2004; Zhou et al. 2009). As a C4 plant, the S. alterniflora has higher photosynthetic efficiency and water use efficiency than the native species Scirpus mariqueter (Cheng et al. 2006; Liao et al. 2007; Ge et al. 2015). Previous researches revealed that plant invasion could have distinct impacts on soil elemental distribution and transformation (Yu et al. 2015; Feng et al. 2018).

Sulfur (S) plays a vital role in plant physiological processes, while high soil S levels can be phytotoxic (Lamers et al. 2013). The S. alterniflora can raise soil S contents and generate environmental stress on native species during its invasion (Xia et al. 2015). Soil organic matter and total S content increase can promote the reduction of sulfate, leading to phytotoxic sulfide accumulation in soil (Li et al. 2019). Soil sulfide content can alter the composition and distribution of vegetation depending on its sulfide tolerance 
level (Li et al. 2009). High soil sulfide levels can inhibit plant growth by reducing oxidase activity in cell mitochondria (Bagarinao 1992). Previous research indicated that increased organic matter input could result in higher soil sulfide levelsby increasing $S$ mineralization and offering substrate for sulfur-reducing bacteria (Scherer 2009). S. alterniflora is a high sulfur-tolerant wetland plant than lots of native plants since it can absorb sulfides and perform sulfide oxidation at the root zone (Carlson and Forrest 1982; Holmer et al. 2002; Martin et al. 2019). The plant S storage in S. alterniflora tissues was found significantly higher than that in native species (Chambers et al. 1998; Zhou et al. 2009).

The $S$. alterniflora invasion impacts soil S cycle-associated microbial activities. Sulfate can be reduced to sulfide by sulfur-reducing bacteria (SRB) in anoxic environments (Niu et al. 2021). The sulfur-oxidizing bacteria (SOB) changes $S^{2-}$ to a higher valence state (Xing et al. 2007). Both SRB and SOB play significant roles in the $S$ cycle and the distribution of soil $S$ forms. Our previous research found that $S$. alterniflora invasion into coastal salt marsh promoted SRB activities and soil S accumulation, which promots the invasion of the sulfur tolerant plant (Zheng et al. 2017). Zeleke et al. (2013) found that the $d s r B$ (SRB) gene copy number in the soil of $S$. alterniflora invaded area was 2.9 times higher than that in the soil of $P$. australis. Cui et al. (2017) found that $S$. alterniflora invasion significantly increased the abundance and diversity of soil SRB community in China's eastern coast. There is still a lack of systematic research on how $S$. alterniflora initiateits invasion by affecting microorganisms related to the S cycle.

We aim to investigate the impacts of $S$. alterniflora invasion on the $S$ cycle and associated soil microbial communities. We hypothesized that (1) the invasion of $S$. alterniflora could increase SOC and TN; (2) $S$. alterniflora invasion altered soil S cycling associated microorganisms and resulted in an increase in sulfate reduction and a change in sulfide in the Jiuduansha Wetland; (3) increased soil sulfide level can environmentally stress on native species $S$. mariqueter, whereas $S$. alterniflora can survive under high sulfide levels. To test these hypotheses, a field investigation was carried out in the Jiuduansha Wetland, and seed germination experiments were conducted in the laboratory. This study will provide a new perspective for explaining the rapid invasion of $S$. alterniflora and provide a detailed reference for subsequent ecological protection.

\section{Materials And Methods \\ 2.1. Site description}

The study was conducted in the Zhongxiasha area $\left(30^{\circ} 10^{\prime} \mathrm{N}, 122^{\circ} 01^{\prime} \mathrm{E}\right)$ of the Jiuduansha Wetland National Nature Reservein China (Fig. 1). The Jiuduansha Wetland is approximately $423 \mathrm{~km}^{2}$ and has a subtropical monsoon climate with an average annual temperature of $15-17^{\circ} \mathrm{C}$ and annual precipitation of about $1200 \mathrm{~mm}$. Before the introduction of S. alterniflora, S. mariqueter was the local pioneer species in this region. After introducing $S$. alterniflora, it quickly underwent an ecological invasion and was widely distributed in the Jiuduansha Wetland. It is now a widespread intertidal species (Huang and Zhang 2007). S. alterniflora is mainly distributed in medium-low tidal flats of the Zhongxiasha area, and $S$. 
mariqueter is the pioneer plant in the Jiuduansha Wetland. It is distributed in low tidal flats (Yang and Guo 2018).

\subsection{Sample collection and analyses}

As shown in Fig. 1, we chose a mudflat without vegetation, a community containing the native species $S$. mariqueter, and a community containing the invasive plant $S$. alterniflora. The mudflat, $S$. mariqueter, and S. alterniflora sites were distributed successively in the same region from sea to land. The elevation of the offshore site was low, while that of the inshore site was high. Soil samples were collected in August and November of 2018 and in January and April of 2019 and represented different temperature and humidity features in the four seasons of spring, summer, autumn, and winter. Each sampling site was randomly sampled three times over a distance of no less than 10 meters. The stem height and density of the vegetation were measured in situ. Total above-ground plant biomass was measured by drying plant samples until constant weight at $65^{\circ} \mathrm{C}$ in an oven.

Soil cores were collected from depths of 0 to $100 \mathrm{~cm}$ by using a columnar sampler. The soil samples were kept in ziplock bags and stored at $4^{\circ} \mathrm{C}$. The samples used for further analyses of sulfide and DNA extraction were stored at $-20^{\circ} \mathrm{C}$. The soil moisture content was determined by drying at $105^{\circ} \mathrm{C}$ in an oven until constant weight. The samples for other physicochemical analyses were air-dried, ground, and passed through a $0.15 \mathrm{~mm}$ sieve. Soil $\mathrm{pH}(1: 2.5)$ was measured in the bulk soil with a pH meter (PHS-25, China), and soil salinity (1:5) was measured with a conductivity meter (Orion 145A+, ThermoFisher Scientific, FL, USA). The soil organic carbon (SOC) content was measured with a potassium dichromate oxidation method (Wang et al. 2019). The soil sulfate content was measured using abarium sulfate turbidimetry method (Chen et al. 2018). Soil total phosphorus (TP) and total iron (Fe) levels were determined by ICP-AES (Teledyne Leeman Labs, Hudson, NH, USA) after soil digestion. Soil sulfide contents were determined as described by Niu et al. (2018). The soil sulfide contents were determined using the methylene blue spectrophotometry method (HJ883-2017) (Luo et al. 2018).

\subsection{Soil functional bacterial measurements}

The total DNA in a representative bulk soil sample from the $S$. mariqueter, $S$. alterniflora, and mudflat sites was extracted using a MetaV $x^{T M}$ according to the manufacturer's protocol (GENEWIZ, Inc., South Plainfield, NJ, USA). The quality of the extracted DNA was assayed using a Qubit 2.0 fluorometer (Invitrogen, Carlsbad, CA) to determine DNA sample concentrations, and a series of PCR primers were designed to amplify two highly variable regions (V3 and V4) of 16S rDNA using 30-50 ng of DNA as a template. The $\mathrm{V} 3$ and $\mathrm{V} 4$ regions were amplified using an upstream primer with the sequence 'CCTACGGRRBGCASCAGKVRVGAAT' and a downstream primer with the sequence 'GGACTACNVGGGTWTCTAATCC'. Additionally, a linker with an index was added to the end of the PCR product of $16 \mathrm{~S}$ rDNA by PCR for NGS. Library quality was determined using an Agilent 2100 Bioanalyzer (Agilent Technologies, Palo Alto, CA, USA), and library concentrations were determined with a Qubit 2.0 fluorometer (Invitrogen, Carlsbad, CA). After the DNA libraries were mixed, 2×300 bp paired-end (PE) sequencing was performed according to the Illumina MiSeq (Illumina, San Diego, CA, USA) instrument 
instruction manual, and sequence information was read by MiSeq Control Software (MCS), which was included with the MiSeq device. For the high-throughput sequencing results, we referred to the classification method of Meyer et al. (2016). We divided the sulfur-related microbial communities in the high-throughput sequencing results into two categories: SRB and SOB, which can respectively reduce sulfate and oxidize sulfide. The quantitative microbial element cycling (QMEC), a high-throughput quantitative-PCR-based chip, was used to obtain the specific functional genes, including sulfur-reducing (dsr $A$ and $d s r B$ ) and sulfur-oxidizing (sox $Y$ and yedZ) functional genes, for the $S$ cycle (Zheng et al. 2018).

\subsection{Seed germination under different sulfide levels}

A lab-scale seed germination experiment with both $S$. alterniflora and $S$. mariqueter seeds was carried out to test their tolerance and survivability of sulfide under different sulfide levels. S. alterniflora and $S$. mariqueter seeds were collected from sampling sites in the Jiuduansha Wetland in autumn 2018. The seeds were soaked in $5 \%$ sodium chloride solution at $4^{\circ} \mathrm{C}$ to preserve the vigor of seeds (Vertucci and Roos 1990). The experiment was conducted in the phytotron of the School of Environmental and Chemical Engineering, Shanghai University, in 2019 , and the temperature was controlled at $28^{\circ} \mathrm{C}$ (day) / $20^{\circ} \mathrm{C}$ (night) (Ricketts et al. 2018), the relative humidity was $80 \%$, and the daily light duration was $12 \mathrm{~h}$.

Twenty seeds of $S$. alterniflora and $S$. mariqueter were disinfected with $0.1 \%$ sodium hypochlorite solution and rinsed with distilled water. Then the seeds were placed in Petri dishes that were cleaned and disinfected in advance. Three replications were conducted for each treatment. The dishes contained the same amount of washed and disinfected silica sand, and $10 \mathrm{~mL}$ of sodium sulfide $\left(\mathrm{Na}_{2} \mathrm{~S}\right)$ solution from a gradient $(0,10,20,50,100$ and $200 \mathrm{mmol} / \mathrm{L})$ was added, because $200 \mathrm{mmol} / \mathrm{L} \mathrm{Na}{ }_{2} S$ was reported to kill S. alterniflora (Shen et al. 2011). After silica sand and $\mathrm{Na}_{2} \mathrm{~S}$ solution being thoroughly mixed, $5 \mathrm{~mL}$ of distilled water was added, while $15 \mathrm{~mL}$ of distilled water was added to the control group. The weight of each Petri dish was then recorded. The Petri dishes were placed in a phytotron, and distilled water was added every 24 hours to reach the original weight. The plant biomass, root length, shoot lengths were weighed and measured with electronic balance and rulers after 7 days of seed culture.

\subsection{Data analysis}

The stem height, stem density, and above-ground biomass of $S$. alterniflora and $S$. mariqueter were calculated by averaging morphological data of four seasons in field investigation. The soil water content, $\mathrm{pH}$, and salinity in five soil layers $(0-20 \mathrm{~cm}, 20-40 \mathrm{~cm}, 40-60 \mathrm{~cm}, 60-80 \mathrm{~cm}$, and $80-100 \mathrm{~cm})$ in the range of $0-100 \mathrm{~cm}$ were calculated by averaging the values of four seasons. The soil sulfide and sulfate concentrations of different seasons were calculated by averaging the data in five depths, and significant differences between four seasons were analyzed using analysis of variance. The annual average sulfide, sulfate, SOC, TN, TP, and total iron concentrations in soil were calculated by averaging all data in five depths and four seasons. Statistically significant differences between vegetation types were analyzed using one-way analysis of variance and Tukey's range test at $5 \%$ significance level (Dat et al. 2000). All reported differences were statistically significant at a $P<0.05$ level. The above statistical analyses of the 
data were performed using SPSS 18.0 (SPSS for Windows, SPSS, Inc.), and diagrams were created with OriginPro 8.5. The relationships between sulfide and soil parameters (water content, SOC, TN, TP, Fe, sulfide, sulfate) were analyzed using principal component analysis (PCA) using Origin 8.5 software and Pearson correlation analysis using SPSS 18.0. A principal coordinates analysis (PcoA) was also applied, to explore the difference of bacterial communities among the soils collected from different sites.

\section{Results}

\subsection{Vegetation and soil properties}

As shown in Table 1, the plant stem height and above-ground biomass of S. alterniflora were 8 and 3 times higher than those of $S$. mariqueter, respectively. In contrast,the stem density of $S$. alterniflora was significantly lower than that of $S$. mariqueter. Both soil moisture content and salinity in S. alterniflora invaded area were higher than those in $S$. mariqueter and mudflat soils. In contrast, the $S$. alterniflora invaded area's soil pH was lower than that in the mudflat soil. 
Table 1

Vegetation and soil properties of three sampling sites (Mudflat (MF); S. mariqueter(SM); S. alterniflora $(\mathrm{SA})$ ). The data are expressed as means \pm SDs, which are the annual averages

\begin{tabular}{|c|c|c|c|c|c|c|c|}
\hline $\begin{array}{l}\text { Sample } \\
\text { Site }\end{array}$ & $\begin{array}{l}\text { Depth } \\
\text { (cm) }\end{array}$ & $\begin{array}{l}\text { Stem } \\
\text { height(cm) }\end{array}$ & $\begin{array}{l}\text { Stem } \\
\text { density } \\
\text { (individual } \\
\text { plants } / \mathrm{m}^{2} \text { ) }\end{array}$ & $\begin{array}{l}\text { Above-ground } \\
\text { plant } \\
\text { biomass }\left(\mathrm{g} / \mathrm{m}^{2}\right)\end{array}$ & $\begin{array}{l}\text { Water } \\
\text { content } \\
\text { (\%wt.) }\end{array}$ & $\begin{array}{l}\mathrm{pH} \\
(0- \\
100 \mathrm{~cm})\end{array}$ & $\begin{array}{l}\text { Salinity } \\
(0- \\
100 \mathrm{~cm})\end{array}$ \\
\hline \multirow[t]{5}{*}{ MF } & $0-20$ & \multirow[t]{5}{*}{$\begin{array}{l}00.00 \pm \\
00.00 \mathrm{c}\end{array}$} & \multirow[t]{5}{*}{$\begin{array}{l}00.00 \pm \\
00.00 \mathrm{c}\end{array}$} & \multirow[t]{5}{*}{$00.00 \pm 00.00 \mathrm{~b}$} & $\begin{array}{l}27.45 \pm \\
1.55\end{array}$ & $\begin{array}{l}8.67 \pm \\
0.38\end{array}$ & $\begin{array}{l}0.25 \pm \\
0.09\end{array}$ \\
\hline & $\begin{array}{l}20- \\
40\end{array}$ & & & & $\begin{array}{l}26.00 \pm \\
2.17\end{array}$ & $\begin{array}{l}8.67 \pm \\
0.32\end{array}$ & $\begin{array}{l}0.25 \pm \\
0.11\end{array}$ \\
\hline & $\begin{array}{l}40^{-} \\
60\end{array}$ & & & & $\begin{array}{l}25.83 \pm \\
2.06\end{array}$ & $\begin{array}{l}8.68 \pm \\
0.34\end{array}$ & $\begin{array}{l}0.28 \pm \\
0.11\end{array}$ \\
\hline & $\begin{array}{l}60- \\
80\end{array}$ & & & & $\begin{array}{l}26.53 \pm \\
1.52\end{array}$ & $\begin{array}{l}8.57 \pm \\
0.36\end{array}$ & $\begin{array}{l}0.23 \pm \\
0.08\end{array}$ \\
\hline & $\begin{array}{l}80- \\
100\end{array}$ & & & & $\begin{array}{l}26.17 \pm \\
1.60\end{array}$ & $\begin{array}{l}8.60 \pm \\
0.40\end{array}$ & $\begin{array}{l}0.28 \pm \\
0.11\end{array}$ \\
\hline \multirow[t]{5}{*}{$S M$} & $0-20$ & \multirow[t]{5}{*}{$\begin{array}{l}20.80 \pm \\
11.83 \mathrm{~b}\end{array}$} & \multirow[t]{5}{*}{$\begin{array}{l}757.33 \pm \\
243.65 a\end{array}$} & \multirow[t]{5}{*}{$\begin{array}{l}501.00 \pm 128.12 \\
a\end{array}$} & $\begin{array}{l}25.56 \pm \\
0.24\end{array}$ & $\begin{array}{l}8.71 \pm \\
0.39\end{array}$ & $\begin{array}{l}0.33 \pm \\
0.08\end{array}$ \\
\hline & $\begin{array}{l}20- \\
40\end{array}$ & & & & $\begin{array}{l}26.99 \pm \\
1.25\end{array}$ & $\begin{array}{l}8.40 \pm \\
0.42\end{array}$ & $\begin{array}{l}0.38 \pm \\
0.15\end{array}$ \\
\hline & $\begin{array}{l}40- \\
60\end{array}$ & & & & $\begin{array}{l}26.80 \pm \\
1.03\end{array}$ & $\begin{array}{l}8.62 \pm \\
0.38\end{array}$ & $\begin{array}{l}0.38 \pm \\
0.11\end{array}$ \\
\hline & $\begin{array}{l}60- \\
80\end{array}$ & & & & $\begin{array}{l}26.50 \pm \\
0.75\end{array}$ & $\begin{array}{l}8.67 \pm \\
0.35\end{array}$ & $\begin{array}{l}0.33 \pm \\
0.11\end{array}$ \\
\hline & 100 & & & & $\begin{array}{l}27.12 \pm \\
0.85\end{array}$ & $\begin{array}{l}8.72 \pm \\
0.36\end{array}$ & $\begin{array}{l}0.33 \pm \\
0.13\end{array}$ \\
\hline \multirow[t]{5}{*}{ SA } & $0-20$ & \multirow{5}{*}{$\begin{array}{l}165.50 \pm \\
70.71 \mathrm{a}\end{array}$} & \multirow{5}{*}{$\begin{array}{l}278.67 \pm \\
127.58 \mathrm{~b}\end{array}$} & \multirow{5}{*}{$\begin{array}{l}1672.25 \pm \\
950.60 \mathrm{a}\end{array}$} & $\begin{array}{l}28.93 \pm \\
1.06\end{array}$ & $8.57 \pm$ & $0.35 \pm$ \\
\hline & $\begin{array}{l}20- \\
40\end{array}$ & & & & $\begin{array}{l}26.77 \pm \\
1.35\end{array}$ & $\begin{array}{l}8.60 \pm \\
0.29\end{array}$ & $\begin{array}{l}0.35 \pm \\
0.11\end{array}$ \\
\hline & $\begin{array}{l}40^{-} \\
60\end{array}$ & & & & $\begin{array}{l}27.67 \pm \\
0.46\end{array}$ & $\begin{array}{l}8.52 \pm \\
0.25\end{array}$ & $\begin{array}{l}0.38 \pm \\
0.11\end{array}$ \\
\hline & $\begin{array}{l}60- \\
80\end{array}$ & & & & $\begin{array}{l}27.91 \pm \\
1.28\end{array}$ & $\begin{array}{l}8.55 \pm \\
0.33\end{array}$ & $\begin{array}{l}0.30 \pm \\
0.12\end{array}$ \\
\hline & $\begin{array}{l}80- \\
100\end{array}$ & & & & $\begin{array}{l}27.47 \pm \\
2.13\end{array}$ & $\begin{array}{l}8.52 \pm \\
0.32\end{array}$ & $\begin{array}{l}0.33 \pm \\
0.08\end{array}$ \\
\hline
\end{tabular}

The sulfide concentrations of soils from the mudflat were generally the lowest, with an average value of $22.10 \pm 19.87 \mathrm{mg} / \mathrm{kg}$. The sulfide concentrations in $S$. mariqueter soil were higher than those in the mudflat soil, with an average value of $79.65 \pm 65.53 \mathrm{mg} / \mathrm{kg}$. The highest sulfide concentration was 
observed in S. alterniflora soil $(210.97 \pm 133.41 \mathrm{mg} / \mathrm{kg})$, which was 9.56 and 2.65 times higher than that in the mudflat and $S$. mariqueter soils, respectively (Fig. 2A). The soil sulfide concentrations were generally higher in spring and summer and relatively lower in the rest of the year regardless of vegetation type (Table 2). The annual average sulfate content in the soils was not significantly different among soils covered by $S$. alterniflora and the native species $S$. mariqueter and in the nearby bare mudflat. The sulfate content in S. mariqueter soil was $295.74 \pm 108.80 \mathrm{mg} / \mathrm{kg}$, while that in S. alterniflora was $268.75 \pm 129.61$ $\mathrm{mg} / \mathrm{kg}$ (Fig. 2B). The sulfate content in S. mariqueter soil ( $340.44 \pm 28.04 \mathrm{mg} / \mathrm{kg})$ in autumn was higher than in S. alterniflora soil (Table 2). In spring, the sulfate content in S. alterniflora soil (458.88 \pm 64.43 $\mathrm{mg} / \mathrm{kg})$ was higher than that in $S$. mariqueter soil $(425.66 \pm 82.64 \mathrm{mg} / \mathrm{kg})$ and mudflat soil $(320.51 \pm$ $115.1 \mathrm{mg} / \mathrm{kg}$ ). Among soils covered by $S$. alterniflora and $S$. mariqueter and in the nearby bare mudflat, the sulfate contents were generally higher in spring and summer (Table 2).

Table 2

Concentrations of sulfide $(\mathrm{mg} / \mathrm{kg})$ and sulfate $(\mathrm{mg} / \mathrm{kg})$ in the soil of mudflat (MF), S. mariqueter (SM), $S$. alterniflora (SA) of four different seasons. Different letters indicate significant differences $(P<0.05)$ between soil sulfide and sulfate concentrations in different seasons

\begin{tabular}{|c|c|c|c|c|c|}
\hline Locations & Sulfide/Sulfate & Spring & Summer & Autumn & Winter \\
\hline \multirow[t]{2}{*}{ MF } & $\begin{array}{l}\text { Sulfide } \\
(\mathrm{mg} / \mathrm{kg})\end{array}$ & $25.98 \pm 24.16 b$ & $\begin{array}{l}44.62 \pm 13.39 \\
a\end{array}$ & $7.26 \pm 1.77 c$ & $\begin{array}{l}10.56 \pm 4.04 \\
\text { bc }\end{array}$ \\
\hline & $\begin{array}{l}\text { Sulfate } \\
(\mathrm{mg} / \mathrm{kg})\end{array}$ & $\begin{array}{l}320.51 \pm \\
115.10 \mathrm{a}\end{array}$ & $\begin{array}{l}253.27 \pm 5.49 \\
b\end{array}$ & $\begin{array}{l}242.51 \pm \\
25.82 \mathrm{~b}\end{array}$ & $\begin{array}{l}140.43 \pm \\
34.11 \mathrm{C}\end{array}$ \\
\hline \multirow[t]{2}{*}{ SM } & $\begin{array}{l}\text { Sulfide } \\
\text { (mg/kg) }\end{array}$ & $\begin{array}{l}114.27 \pm 97.17 \\
a\end{array}$ & $\begin{array}{l}115.13 \pm \\
43.48 \mathrm{a}\end{array}$ & $\begin{array}{l}38.58 \pm 37.21 \\
b\end{array}$ & $\begin{array}{l}50.62 \pm 38.07 \\
b\end{array}$ \\
\hline & $\begin{array}{l}\text { Sulfate } \\
(\mathrm{mg} / \mathrm{kg})\end{array}$ & $\begin{array}{l}425.66 \pm 82.64 \\
a\end{array}$ & $\begin{array}{l}265.56 \pm \\
14.70 \mathrm{c}\end{array}$ & $\begin{array}{l}340.44 \pm \\
28.04 \mathrm{~b}\end{array}$ & $\begin{array}{l}151.32 \pm \\
23.40 \mathrm{~d}\end{array}$ \\
\hline \multirow[t]{2}{*}{ SA } & $\begin{array}{l}\text { Sulfide } \\
(\mathrm{mg} / \mathrm{kg})\end{array}$ & $\begin{array}{l}218.19 \pm \\
157.89 b\end{array}$ & $\begin{array}{l}351.07 \pm \\
84.80 \mathrm{a}\end{array}$ & $\begin{array}{l}102.21 \pm \\
75.54 \mathrm{c}\end{array}$ & $\begin{array}{l}172.4 \pm 74.01 \\
\text { bc }\end{array}$ \\
\hline & $\begin{array}{l}\text { Sulfate } \\
\text { (mg/kg) }\end{array}$ & $\begin{array}{l}458.88 \pm 64.43 \\
a\end{array}$ & $\begin{array}{l}277.62 \pm \\
22.18 b\end{array}$ & $\begin{array}{l}210.89 \pm \\
20.44 c\end{array}$ & $\begin{array}{l}127.63 \pm \\
67.56 \mathrm{~d}\end{array}$ \\
\hline
\end{tabular}

The SOC content in $S$. alterniflora soil was $6.77 \pm 1.94 \mathrm{mg} / \mathrm{g}$, which was much higher than that in $S$. mariqueter soil ( $3.68 \pm 1.43 \mathrm{mg} / \mathrm{g}$ ) and mudflat soil ( $3.08 \pm 1.49 \mathrm{mg} / \mathrm{g}$ ) (Fig. 2C). The TN content for $S$. alterniflora soil was $286.65 \pm 64.56 \mathrm{mg} / \mathrm{kg}$, which was higher than that for $S$. mariqueter $(155.57 \pm 36.72$ $\mathrm{mg} / \mathrm{kg}$ ) and mudflat soils $(137.64 \pm 31.42 \mathrm{mg} / \mathrm{kg}$ ) (Fig. 2D). The TP content for $S$. alterniflora soil was $0.47 \pm 0.13 \mathrm{mg} / \mathrm{g}$, which was lower thanthat for the mudflat $(0.52 \pm 0.08 \mathrm{mg} / \mathrm{g})$ and S. mariqueter $(0.55 \pm$ $0.08 \mathrm{mg} / \mathrm{g}$ ) soils (Fig. 2E). The total iron content of $S$. alterniflora soil was $20.72 \pm 2.68 \mathrm{mg} / \mathrm{g}$, and the total iron content of $S$. alterniflora soil was slightly higher than that of the mudflat $(19.95 \pm 1.84 \mathrm{mg} / \mathrm{g})$ and S. mariqueter $(19.93 \pm 2.77 \mathrm{mg} / \mathrm{g}$ ) soils (Fig. $2 \mathrm{~F}$ ).

\subsection{Relationship between sulfide, sulfate, and environmental factors}


In the mudflat soil, the sulfide content was substantially correlated with total iron $(r=0.497, p<0.05)$ and $\operatorname{TP}(r=0.571, p<0.01)$, and sulfate was significantly correlated with $\operatorname{TN}(r=0.668, p<0.01)$. Meanwhile, the total iron was positively correlated with TP in the mudflat soil $(r=0.761, p<0.01)$ (Fig. 3a). In the $S$. mariqueter soil, there was a negative relationship between sulfate and total iron $(r=-0.595, p<0.01)$

(Fig. 3b). In the $S$. alterniflora soil, the sulfide content exhibited a strong correlation with $\operatorname{SOC}(r=0.616, p$ $<0.01)$ and total iron $(r=0.472, p<0.05)$, and sulfate was significantly correlated with TP $(r=0.547, p<$ 0.05). Besides, SOC was positively correlated with total iron and TP, with coefficients of $0.546(p<0.05)$ and $0.468(p<0.05)$, respectively. The total iron in the $S$. alterniflora soil exhibited a significantly positive correlation with TP $(r=0.578, p<0.01)$ (Fig. 3c).

\subsection{Effects of plant invasion on $\mathrm{S}$ cycle-relatedsoil functional bacteria}

The PCoA mapping analysis results based on the Bray-Curtis distance matrix (Fig. 4) showed that the bacterial communities were different among the soils collected from different sites. The PC1 and PC2 axes together accounted for $52.46 \%$ of the variation. The total number of SRB measured at the family level was lower for $S$. alterniflora soil than in the other soils (Fig. 5A). The relative abundance of SRB in $S$. alterniflora soil was 7.32\%, which was lower than that in S. mariqueter soil (14.9\%) and higher than that in mudflat soil (7.28\%). The main groups of SRB in S. alterniflora soil were Desulfobulbaceae, Desulfuromonadales, and Desulfobacteraceae, which accounted for $68.2 \%$ of the SRB S. alterniflora community, and with the invasion of $S$. alterniflora, Nitrospiraceae and Desulfarculaceae increased (Fig. 5A). The relative SOB abundances were lower for S. alterniflora soil (3.03\%) than for S. mariqueter (3.75\%) soiland for mudflat (4.49\%) soil (Fig. 5B). The S. alterniflora communities mainly consisted of Rhodobacteraceae and Hyphomicrobiaceae, while Hydrogenophilaceae was the main SOB component in the mudflat and $S$. mariqueter soils. The QMEC test results showed that the variation trend of the relative abundance of sulfur-reducing functional genes was similar to that of the sulfide content, and the main sulfur-reducing functional gene was $d s r A$. The highest sulfur-reducing functional gene abundance, which was $1.49 \%$, appeared in the soil of $S$. alterniflora, while in the mudflat and $S$. mariqueter soils, the abundances were $1.27 \%$ and $1.17 \%$, respectively (Fig. 5C). The primary sulfur-oxidizing functional gene was yedZ. The lowest abundance of sulfur-oxidizing functional genes was observed in the soil of $S$. alterniflora, which was $0.19 \%$, while in the mudflat and $S$. mariqueter soils, the abundances were $0.25 \%$ and $0.32 \%$, respectively (Fig. 5D).

\subsection{Effects of sulfide on the growth of $S$. alterniflora and $S$. mariqueter}

After seven days of the seed germination experiment, the root length, shoot length, and biomass of $S$. alterniflora and $S$. mariqueter showed variability along the gradients of $\mathrm{Na}_{2} \mathrm{~S}$ incubations (Fig. 6). The root tissues of $S$. mariqueter ceased to grow when the $\mathrm{Na}_{2} \mathrm{~S}$ concentration reached $50 \mathrm{mmol} / \mathrm{L}$. Although low concentrations of $\mathrm{Na}_{2} \mathrm{~S}$ had no significant effect on $S$. alterniflora root length, $S$. alterniflora root length showed a decreasing trend with the increase of $\mathrm{Na}_{2} \mathrm{~S}$ concentration. The root tissue of $S$. 
alterniflora was still alive at the concentration of $\mathrm{Na}_{2} \mathrm{~S}$ was as high as $200 \mathrm{mmol} / \mathrm{L}$ (Fig. 6A). When the concentration of $\mathrm{Na}_{2} \mathrm{~S}$ reached $50 \mathrm{mmol} / \mathrm{L}$, a significant decrease in the shoot lengths of $S$. mariqueter occurred. However, with the increase of the concentration of $\mathrm{Na}_{2} \mathrm{~S}$, there was no significant effect on the shoot lengths of $S$. alterniflora increased (Fig. 6B). $\mathrm{Na}_{2} \mathrm{~S}$ concentrations over $100 \mathrm{mmol} / \mathrm{L}$ significantly reduced $S$. mariqueter plant biomass, while the biomass of $S$. alterniflora remains the same at high levels of $\mathrm{Na}_{2} \mathrm{~S}$ concentration (Fig. 6C).

\section{Discussion}

\subsection{S. alterniflora might increase soil microbial biomass and activity by increasing soil SOC and TN}

Our findings suggest that the S. alterniflora invasion leads to increased soil SOC (Fig. 2C) and TN (Fig. 2D), which might provide abundant substrate for more active microbial activity. The increase in plant biomass can promote the input of organic matter, carbon, and nitrogen, which can further change the ratio of carbon and nitrogen, forming a different environment for soil microorganisms (Hu et al. 2016). Plant invasion changes soil properties mainly through the litter and root exudates (Yan et al. 2018), and soil microbial structures were selected by the composition of plant litter. $S$. alterniflora has a more vital ability to enhance above-ground net primary productivity and preserve soil organic carbon than $S$. mariqueter due to the larger biomass of $S$. alterniflora, as above-ground plant biomass is the main input route for soil organic carbon (Carrera et al. 2009). In addition, the increase in soil SOC and TN contents arise due to the higher input of $S$. alterniflora tissue decomposition. Relatively higher nitrogen content was also found in S. alterniflora tissues, which may contribute to the raised soil TN (Zheng et al. 2017).

\subsection{S. alterniflora altered soil S cycle-related microbial activitiesand resulted in soil sulfide accumulation}

We reported that the increase in the abundance of $S$ reduction-relative functional genes ( $d s r A$ and $d s r B)$ and the decrease in the abundance of $S$ oxidation-relative functional genes ( $\operatorname{sox} Y$ and yedZ) were consistent with the increase in phytotoxic soil sulfide after $S$. alterniflorafor the first time. Sulfide is a reductive phytotoxicity in the rapid redox reactions with sulfate under tidal conditions in coastal wetlands (Lamers et al. 2013). According to our investigation, the invasion of S. alterniflora changes the community structure and living environment of soil microorganisms into a more suitable condition for sulfide production and accumulation. The differences between the horizontal and vertical projections of PCoA in the two sets of comparisons of $S$. alterniflora and S. mariqueter implied that these two plants possessed different mechanisms for changingthe microbial community structure in soil (Fig. 4).

The composition and structure of S-associated bacterial communities in the soil were altered after $S$. alterniflora invasion (Fig. 5A). Desulfobulbaceae, Desulfuromonadales, and Desulfobacteraceaeare strictly anaerobic SRB that cantransform sulfates into sulfides in a flooded environment and play a central role in methane formation and dissimilatory sulfate reduction (Kuever 2014). The lower relative 
abundance of Hydrogenophilaceae in the soil of S. alterniflora (Fig. 5B), which is a type of SOB, might lead to the oxidation of reductive soil sulfide being inhibited and further contributed to the accumulation of soil sulfide (Fig. 2A). DsrA and $d s r B$ are functional genes involved in the S cycle; they catalyze the reduction of sulfite $\left(\mathrm{SO}_{3}{ }^{2-}\right)$ to sulfide $\left(\mathrm{S}^{2-}\right)$ in the S cycle (Muyzer and Stams 2008 ). We found that the invasion of $S$. alterniflora promoted the microbial sulfur reduction process by increasing the relative abundance of the $d s r B$ functional gene in the soil and changing their community structure (Fig. 5C), but insignificant change was found in the relative abundance of $d s r A$, thereby led to the increase of soil sulfide content (Fig. 2A). The invasion of $S$. alterniflora resulted in a decrease in the relative abundance of the SOB in the soil (Fig. 5D), which reduced the oxidation of sulfur compounds and led to the accumulation of sulfide compounds (Fig. 2A). The SOB is composed of autotrophs and facultative autotrophs (Mattes et al. 2013), which can consume $\mathrm{H}_{2} \mathrm{~S}$ and produce oxidized $\mathrm{S}$ compounds such as sulfides, elemental sulfur, sulfites, and thiosulfates (Meyer et al. 2016). Therefore, the increasing SOC after S. alterniflora invasion cannot accelerate the growth of SOB. Sox family can ultimately reduce sulfide compounds to sulfate (Friedrich et al. 2001). The sox multienzyme system is considered to be the basic and original molecular mechanism of $S$ oxidation (Ghosh and Dam 2009); yed $Z$ is considered to have a sulfite oxidation function (Brokx et al. 2005; Zheng et al. 2018).

In 2017, our team found an increase in the copy numbers of the $d s r B$ functional gene in SRB after $S$. alterniflora invasion in Dongtan Saltmarsh located in Chongming Island (Zheng et al. 2017), but no significant variation in sox $B$ was observed. It might because the sampling sites of $S$. alterniflora were invaded for over 20 years with stable soil physicochemical properties and microbial structure. Previous studies have found the $d s r A B$ coded by the $d s r$ genes in certain strains of $S O B$, it may lead to the insignificant variation in sox observed with the offset by increasing dsrAB (Loy et al. 2009). In the researches of Cui and Zeleke, a higher abundance of $d s r B$ genes was observed in the soil of $S$. alterniflora than the native species Suaeda salsa (S. salsa) and $P$. australis in the Dongtan Wetland in the Yangtze River estuary and Yancheng Nature Reserve, which consisted with our findings (Zeleke et al. 2013; Cui et al. 2017).

\subsection{S. alterniflora invade successfully with its high tolerance to high sulfide concentration}

A higher tolerance to sulfide was revealed in S. alterniflora, since the decrease in S. alterniflora biomass was much smaller than that of $S$. mariqueter biomass (Fig. 6A) and the negative effect on the growth of $S$. alterniflora roots and shoots was significantly weaker than that on the growth of $S$. mariqueter roots and shoots (Fig. 6B, 6C), according to our lab experiment. The phytotoxicity of sulfide mainly influences the growth of roots suppressing water and nutrients absorption from the soil, which was consistent with published results that the toxicity of sulfide toplants mainly affects roots by preventing the roots from transporting energy needed for plant growth (Raven and Scrimgeour 1997).

Our findings confirmed that $S$. alterniflora is a high-sulfur-tolerant plant with a variety of mechanisms to resist sulfide toxicity, such as secretion of oxygen from roots, oxidation of sulfides in tissues (Carlson and 
Forrest 1982; Martin et al. 2019) and formation of insoluble iron sulfide metals (Marbà et al. 2007). More developed root tissues in $S$. alterniflora than in the native species $P$. australis and $S$. mariqueter also lead to more resistant vitality of $S$. alterniflora under high sulfide conditions (Stribling 1997; Seliskar et al. 2004). Iron can form FeS and $\mathrm{FeS}_{2}$ with $\mathrm{S}$ to reduce sulfide toxicity (Van Der Welle et al. 2006; Marbà et al. 2007; Sjøgaard et al. 2017). Thus, the accumulation of high levels of iron in the soil of S. alterniflora might be one of the mechanisms by which $S$. alterniflora resists the toxicity of sulfides. Simkin et al. (2013) proved that sulfide in pore water helps explain the reduction in plant species diversity and the reduction in coverage of many plant species. However, we did not observe significant variation in soil Fe content.

Compared with the $S$. mariqueter and mudflat soils, S. alterniflora soil showed the shortest anaerobic reduction environment and shortest flooding time caused by its location in the most inland area. Under such flooding conditions, the highest sulfide content was still found in the soils of $S$. alterniflora. Thus, native species lacking sulfide tolerance capacities could be disadvantaged in the competition with $S$. alterniflora due to the high soil sulfide content derived from soil S-cycle microbial changes after $S$. alterniflora invasion was more lethal to the growth of local species.

\section{Conclusions}

We found that $S$. alterniflora invasion significantly altered the physicochemical properties of the soil and sulfur-related bacterial community. First, the contents of SOC and TN in soil increased with the invasion of $S$. alterniflora, which could provide more substrates for sulfur-reducing bacteria to cause sulfide accumulation in the soil. Second, the abundance of sulfur-oxidizing functional genes decreased after the invasion of $S$. alterniflora and thus reduced the consumption of sulfide, possibly through root exudates and litter pathways. Third, the phytotoxicity of the increased soil sulfide levels caused much more lethal damage to $S$. mariqueter than to $S$. alterniflora, so that $S$. alterniflora could survive in a high-sulfide environment while $S$. mariqueter could not. Our findings provide a new perspective on how $S$. alterniflora is able to rapidly replace the native species $S$. mariqueter in the Jiuduansha Wetland.

\section{Declarations}

\section{Acknowledgments}

This study was financially supported by the Natural Science Foundation (41971055ه41907270), State's Key Project of Research and Development Plan (2016YFA0601003), great thanks to the group who provided invaluable support while the samples were collected.

Funding: This study was financially supported by the Natural Science Foundation (41971055ه41907270), State's Key Project of Research and Development Plan (2016YFA0601003).

Conflicts of interest: The authors declare that they have no known competing financial interests or personal relationships that could have appeared to influence the work reported in this paper. 
Availability of data and material: Data can be provided under reasonable request by contacting the corresponding ahthor.

\section{References}

1. Bagarinao $T$ (1992) Sulfide as an environmental factor and toxicant: tolerance and adaptations in aquatic organisms. Aquat Toxicol 24:21-62. https://doi.org/10.1016/0166-445x(92)90015-f

2. Brokx SJ, Rothery RA, Zhang G et al (2005) Characterization of an Escherichia coli sulfite oxidase homologue reveals the role of a conserved active site cysteine in assembly and function. Biochemistry 44:10339-10348. https://doi.org/10.1021/bi050621a

3. Carlson PR, Forrest J (1982) Uptake of dissolved sulfide by Spartina alterniflora: Evidence from natural sulfur isotope abundance ratios. Science 216:633-635. https://doi.org/10.1126/science.216.4546.633

4. Carrera AL, Mazzarino MJ, Bertiller MB et al (2009) Plant impacts on nitrogen and carbon cycling in the Monte Phytogeographical Province, Argentina. J Arid Environ 73:192-201. https://doi.org/10.1016/j.jaridenv.2008.09.016

5. Chambers RM, Mozdzer TJ, Ambrose JC (1998) Effects of salinity and sulfide on the distribution of Phragmites australis and Spartina alterniflora in a tidal saltmarsh. Aquat Bot 62:161-169. https://doi.org/10.1016/S0304-3770(98)00095-3

6. Chen XP, Sun J, Wang Y et al (2018) Temporal and spatial impact of Spartina alterniflora invasion on methanogens community in Chongming Island, China. J Microbiol 56:507-515. https://doi.org/10.1007/s12275-018-8062-y

7. Cheng X, Luo Y, Chen J et al (2006) Short-term C4 plant Spartina alterniflora invasions change the soil carbon in C3 plant-dominated tidal wetlands on a growing estuarine Island. Soil Biol Biochem 38:3380-3386. https://doi.org/10.1016/j.soilbio.2006.05.016

8. Chung CH, Zhuo RZ, Xu GW (2004) Creation of Spartina plantations for reclaiming Dongtai, China, tidal flats and offshore sands. Ecol Eng 23:135-150. https://doi.org/10.1016/j.ecoleng.2004.07.004

9. Cui J, Chen X, Nie M et al (2017) Effects of Spartina alterniflora Invasion on the Abundance, Diversity, and Community Structure of Sulfate Reducing Bacteria along a Successional Gradient of Coastal Salt Marshes in China. Wetlands 37:221-232. https://doi.org/10.1007/s13157-016-0860-6

10. Dat J, Vandenabeele S, Vranová E et al (2000) Dual action of the active oxygen species during plant stress responses. Cell Mol Life Sci 57:779-795. https://doi.org/10.1007/s000180050041

11. Feng $\mathrm{H}$, Qian $\mathrm{Y}$, Cochran JK et al (2018) Seasonal differences in trace element concentrations and distribution in Spartina alterniflora root tissue. Chemosphere 204:359-370. https://doi.org/10.1016/j.chemosphere.2018.04.058

12. Friedrich CG, Rother D, Bardischewsky F et al (2001) Oxidation of Reduced Inorganic Sulfur Compounds by Bacteria: Emergence of a Common Mechanism? Appl Environ Microbiol 67:28732882. https://doi.org/10.1128/AEM.67.7.2873-2882.2001 
13. Ge ZM, Guo HQ, Zhao B, Zhang LQ (2015) Plant invasion impacts on the gross and net primary production of the salt marsh on eastern coast of China: Insights from leaf to ecosystem. J Geophys Res G Biogeosciences 120:169-186. https://doi.org/10.1002/2014jg002736

14. Ghosh W, Dam B (2009) Biochemistry and molecular biology of lithotrophic sulfur oxidation by taxonomically and ecologically diverse bacteria and archaea. FEMS Microbiol Rev 33:999-1043. https://doi.org/10.1111/j.1574-6976.2009.00187.x

15. Holmer M, Gribsholt B, Kristensen E (2002) Effects of sea level rise on growth of Spartina anglica and oxygen dynamics in rhizosphere and salt marsh sediments. Mar Ecol Prog Ser 225:197-204. https://doi.org/10.3354/meps225197

16. Hu N, Li H, Tang Z et al (2016) Community size, activity and C: N stoichiometry of soil microorganisms following reforestation in a Karst region. Eur J Soil Biol 73:77-83. https://doi.org/10.1016/j.ejsobi.2016.01.007

17. Huang $H$, Zhang $L$ (2007) A study of the population dynamics of Spartina alterniflora at Jiuduansha shoals, Shanghai, China. Ecol Eng 29:164-172. https://doi.org/10.1016/j.ecoleng.2006.06.005

18. Kuever J (2014) The family desulfobulbaceae. In: The Prokaryotes: Deltaproteobacteria and Epsilonproteobacteria. pp 75-86

19. Lamers LPM, Govers LL, Janssen ICJM et al (2013) Sulfide as a soil phytotoxin-a review. Front Plant Sci 4:. https://doi.org/10.3389/fpls.2013.00268

20. Li N, Nie M, Li B et al (2021) Contrasting effects of the aboveground litter of native Phragmites australis and invasive Spartina alterniflora on nitrification and denitrification. Sci Total Environ 764:. https://doi.org/10.1016/j.scitotenv.2020.144283

21. Li P, Xie W, Wang Z, Yan Q (2019) Effects of Spartina alterniflora invasion on sulfur content temporal and spatial variation in tidal flat wetland of Jiaozhou Bay. Huanjing Kexue Xuebao/Acta Sci Circumstantiae 39:870-879. https://doi.org/10.13671/j.hjkxxb.2018.0416

22. Li S, Mendelssohn IA, Chen H, Orem WH (2009) Does sulphate enrichment promote the expansion of Typha domingensis (cattail) in the Florida Everglades? Freshw Biol 54:1909-1923. https://doi.org/10.1111/j.1365-2427.2009.02242.x

23. Liao $C$, Luo Y, Jiang L et al (2007) Invasion of Spartina alterniflora enhanced ecosystem carbon and nitrogen stocks in the Yangtze Estuary. China Ecosystems 10:1351-1361. https://doi.org/10.1007/s10021-007-9103-2

24. Loy A, Duller S, Baranyi C et al (2009) Reverse dissimilatory sulfite reductase as phylogenetic marker for a subgroup of sulfur-oxidizing prokaryotes. Environ Microbiol 11:289-299. https://doi.org/10.1111/j.1462-2920.2008.01760.x

25. Luo M, Liu Y, Huang J et al (2018) Rhizosphere processes induce changes in dissimilatory iron reduction in a tidal marsh soil: a rhizobox study. Plant Soil 433:83-100. https://doi.org/10.1007/s11104-018-3827-y

26. Mack RN, Simberloff D, Lonsdale WM et al (2000) Biotic invasions: Causes, epidemiology, global consequences, and control. Ecol Appl 10:689-710. https://doi.org/10.2307/2641039 
27. Marbà N, Calleja ML, Duarte CM et al (2007) Iron additions reduce sulfide intrusion and reverse seagrass (Posidonia oceanica) decline in carbonate sediments. Ecosystems 10:745-756. https://doi.org/10.1007/s10021-007-9053-8

28. Martin BC, Bougoure J, Ryan MH et al (2019) Oxygen loss from seagrass roots coincides with colonisation of sulphide-oxidising cable bacteria and reduces sulphide stress. ISME J 13:707-719. https://doi.org/10.1038/s41396-018-0308-5

29. Mattes TE, Nunn BL, Marshall KT et al (2013) Sulfur oxidizers dominate carbon fixation at a biogeochemical hot spot in the dark ocean. ISME J 7:2349-2360. https://doi.org/10.1038/ismej.2013.113

30. Meyer DD, de Andrade PAM, Durrer A et al (2016) Bacterial communities involved in sulfur transformations in wastewater treatment plants. Appl Microbiol Biotechnol 100:10125-10135. https://doi.org/10.1007/s00253-016-7839-3

31. Muyzer G, Stams AJM (2008) The ecology and biotechnology of sulphate-reducing bacteria. Nat Rev Microbiol 6:441-454. https://doi.org/10.1038/nrmicro1892

32. Niu Z, Pan H, Guo X, pan et al (2018) Sulphate-reducing bacteria (SRB) in the Yangtze Estuary sediments: Abundance, distribution and implications for the bioavailibility of metals. Sci Total Environ 634:296-304. https://doi.org/10.1016/j.scitotenv.2018.03.345

33. Niu Z, Yan J, Guo X, pan et al (2021) Human activities can drive sulfate-reducing bacteria community in Chinese intertidal sediments by affecting metal distribution. Sci Total Environ 786:. https://doi.org/10.1016/j.scitotenv.2021.147490

34. Raven JA, Scrimgeour CM (1997) The influence of anoxia on plants of saline habitats with special reference to the sulphur cycle. Ann Bot 79:79-86.

https://doi.org/10.1093/oxfordjournals.aob.a010309

35. Ricketts MP, Flower CE, Knight KS, Gonzalez-Meler MA (2018) Evidence of ash tree (Fraxinus spp.) specific associations with soil bacterial community structure and functional capacity. Forests 9 :. https://doi.org/10.3390/f9040187

36. Sanderson EW, Foin TC, Ustin SL (2001) A simple empirical model of salt marsh plant spatial distributions with respect to a tidal channel network. Ecol Modell 139:293-307. https://doi.org/10.1016/S0304-3800(01)00253-8

37. Scherer HW (2009) Sulfur in soils. J Plant Nutr Soil Sci 172:326-335

38. Seliskar DM, Smart KE, Higashikubo BT, Gallagher JL (2004) Seedling sulfide sensitivity among plant species colonizing phragmites-infested wetlands. Wetlands 24:426-433. https://doi.org/10.1672/0277-5212(2004)024[0426:Sssaps]2.0.Co;2

39. Shen W, Lu C, Zhou C (2011) Antioxidant Systems of Spartina alterniflora and Phragmites Australis Responded Differently to Environmental Sulfur Stress. J Fudan Univ 50:653-661. https://doi.org/10.15943/j.cnki.fdxb-jns.2011.05.019

40. Simkin SM, Bedford BL, Weathers KC (2013) Phytotoxic Sulfide More Important than Nutrients for Plants Within a Groundwater-Fed Wetland. Ecosystems 16:1118-1129. 
https://doi.org/10.1007/s10021-013-9671-2

41. Sjøgaard KS, Treusch AH, Valdemarsen TB (2017) Carbon degradation in agricultural soils flooded with seawater after managed coastal realignment. Biogeosciences 14:4375-4389. https://doi.org/10.5194/bg-14-4375-2017

42. Stribling JM (1997) The relative importance of sulfate availability in the growth of Spartina alterniflora and Spartina cynosuroides. Aquat Bot 56:131-143. https://doi.org/10.1016/S03043770(96)01102-3

43. Van Der Welle MEW, Cuppens M, Lamers LPM, Roelofs JGM (2006) Detoxifying toxicants: Interactions between sulfide and iron toxicity in freshwater wetlands. Environ Toxicol Chem 25:1592-1597. https://doi.org/10.1897/05-283r.1

44. Vertucci CW, Roos EE (1990) Theoretical basis of protocols for seed storage. Plant Physiol 94:10191023

45. Wang C, Wang W, Sardans J et al (2020) Higher fluxes of C, N and P in plant/soil cycles associated with plant invasion in a subtropical estuarine wetland in China. Sci Total Environ 730: https://doi.org/10.1016/j.scitotenv.2020.139124

46. Wang Z, Zhang H, He C et al (2019) Spatiotemporal variability in soil sulfur storage is changed by exotic Spartina alterniflora in the Jiuduansha Wetland, China. Ecol Eng 133:160-166. https://doi.org/10.1016/j.ecoleng.2019.04.014

47. Xia L, Yang W, Zhao H et al (2015) High Soil Sulfur Promotes Invasion of Exotic Spartina alterniflora into Native Phragmites australis Marsh. Clean - Soil Air Water 43:1666-1671. https://doi.org/10.1002/clen.201300883

48. Xing Y, Liu CH, An SQ (2007) Microbes and their functions in sulfur cycle of coastal salt marsh sediments. Chinese J Ecol 26:577-581. https://doi.org/10.13292/j.1000-4890.2007.0105

49. Yan J, Wang L, Hu Y et al (2018) Plant litter composition selects different soil microbial structures and in turn drives different litter decomposition pattern and soil carbon sequestration capability. Geoderma 319:194-203. https://doi.org/10.1016/j.geoderma.2018.01.009

50. Yang R-M, Guo W-W (2018) Exotic Spartina alterniflora Enhances the Soil Functions of a Coastal Ecosystem. Soil Sci Soc Am J 82:901-909. https://doi.org/10.2136/sssaj2017.12.0411

51. Yu X, Yang J, Liu L et al (2015) Effects of Spartina alterniflora invasion on biogenic elements in a subtropical coastal mangrove wetland. Environ Sci Pollut Res 22:3107-3115. https://doi.org/10.1007/s11356-014-3568-2

52. Zeleke J, Sheng Q, Wang JG et al (2013) Effects of Spartina alterniflora invasion on the communities of methanogens and sulfate-reducing bacteria in estuarine marsh sediments. Front Microbiol 4: https:// doi.org/10.3389/fmicb.2013.00243

53. Zheng B, Zhu Y, Sardans J et al (2018) QMEC: a tool for high-throughput quantitative assessment of microbial functional potential in C, N, P, and S biogeochemical cycling. Sci China Life Sci 61:14511462. https://doi.org/10.1007/s11427-018-9364-7 
54. Zheng Y, Bu NS, Long XE et al (2017) Sulfate reducer and sulfur oxidizer respond differentially to the invasion of Spartina alterniflora in estuarine salt marsh of China. Ecol Eng 99:182-190. https://doi.org/10.1016/j.ecoleng.2016.11.031

55. Zhou C, An S, Deng Z et al (2009) Sulfur storage changed by exotic Spartina alterniflora in coastal saltmarshes of China. Ecol Eng 35:536-543. https://doi.org/10.1016/j.ecoleng.2008.01.004

\section{Figures}

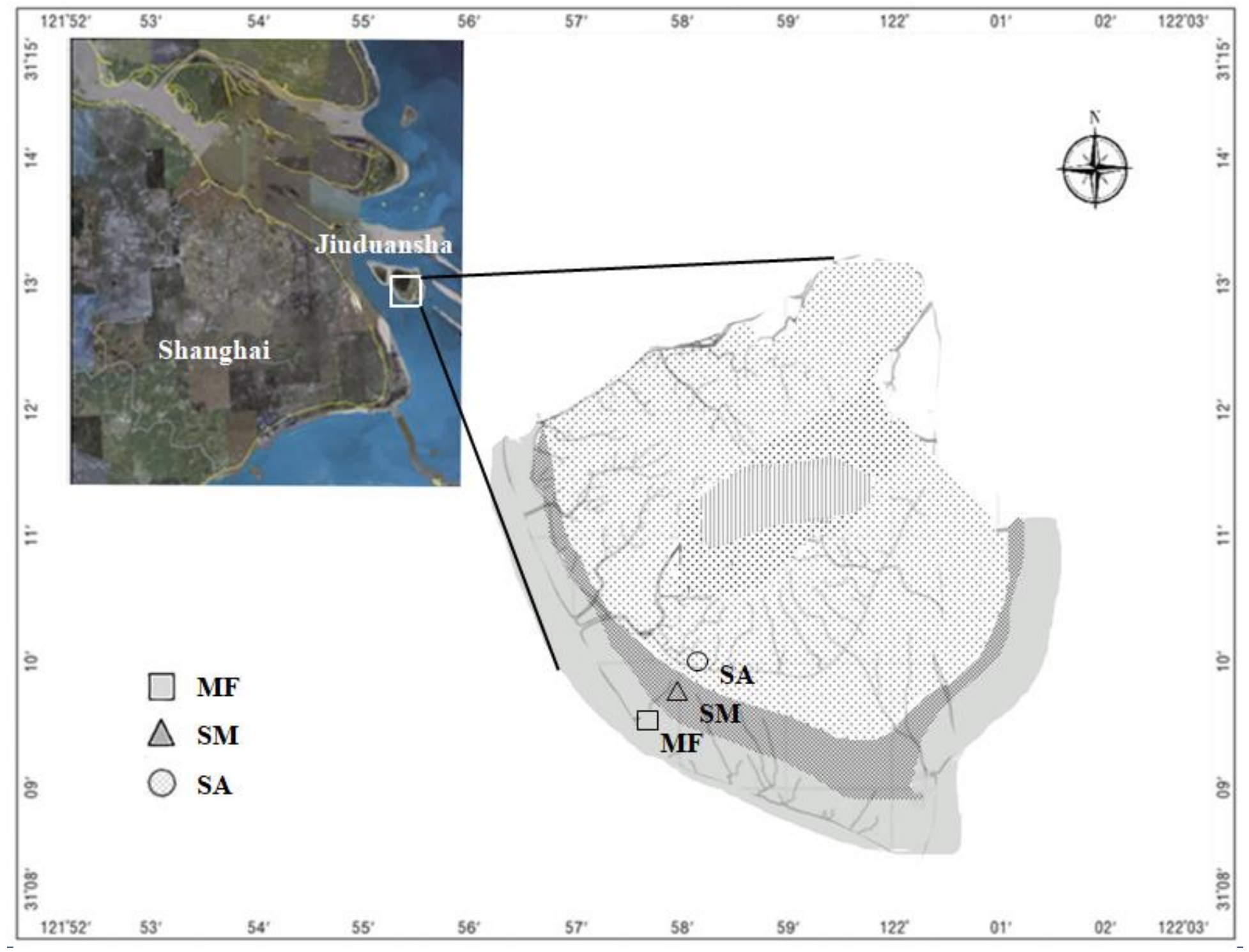

\section{Figure 1}

Sampling locations in the Jiuduansha Wetland National Nature Reserve (Mudflat (MF); S. mariqueter (SM); S. alterniflora (SA)) Note: The designations employed and the presentation of the material on this map do not imply the expression of any opinion whatsoever on the part of Research Square concerning the legal status of any country, territory, city or area or of its authorities, or concerning the delimitation of its frontiers or boundaries. This map has been provided by the authors. 

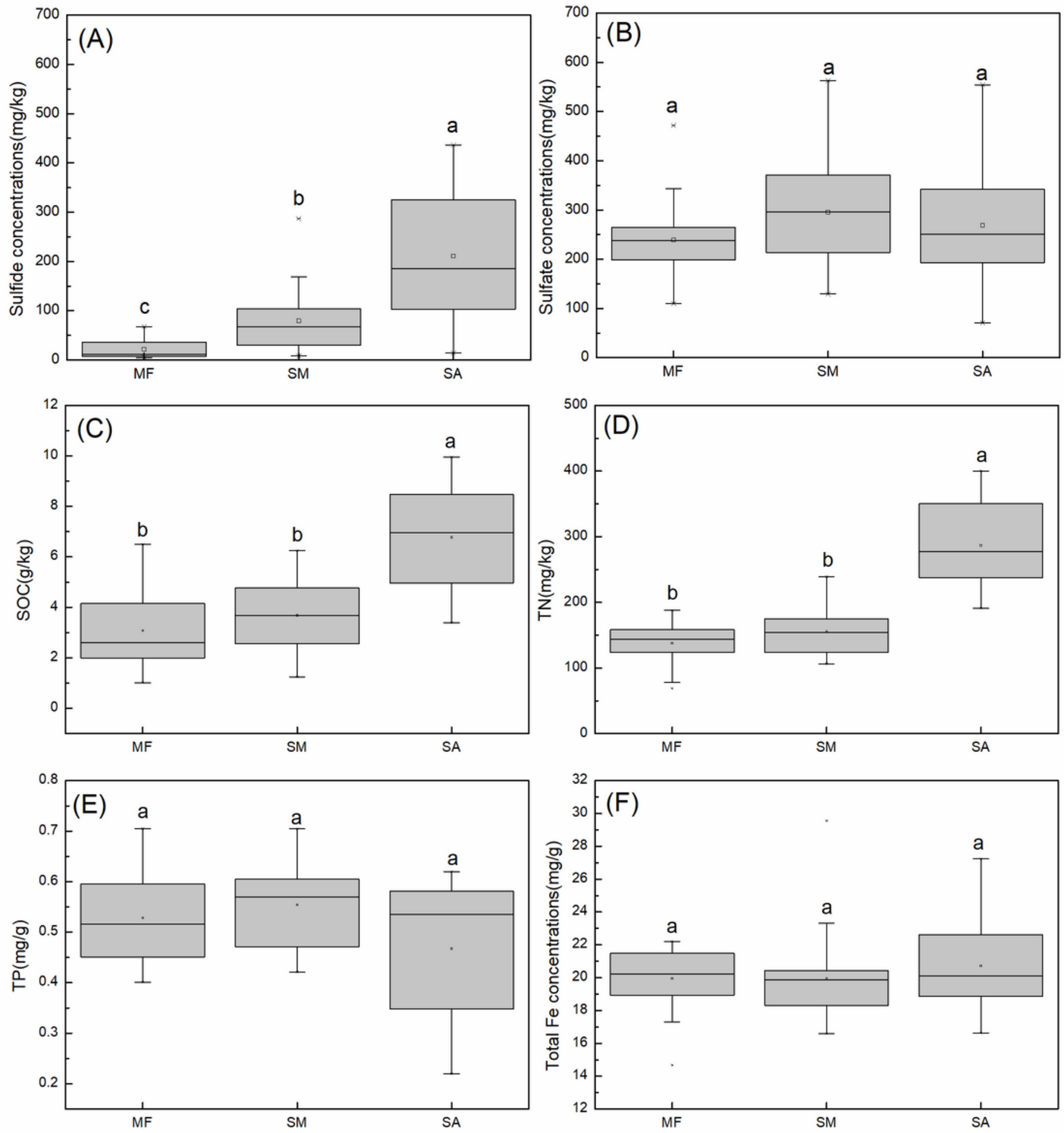

Figure 2

Soil sulfide concentrations (A), sulfate concentrations (B), soil organic carbon (C), total nitrogen (D), total phosphorous (E), and total iron (F) of three sampling sites (Mudflat (MF); S. mariqueter (SM); $S$. alterniflora (SA)). The boxes display the upper and lower quartiles of the data, and whiskers represent the standard deviation above and below the mean of the data. Different letters indicate significant differences between three sampling sites at a $p<0.05$ level 

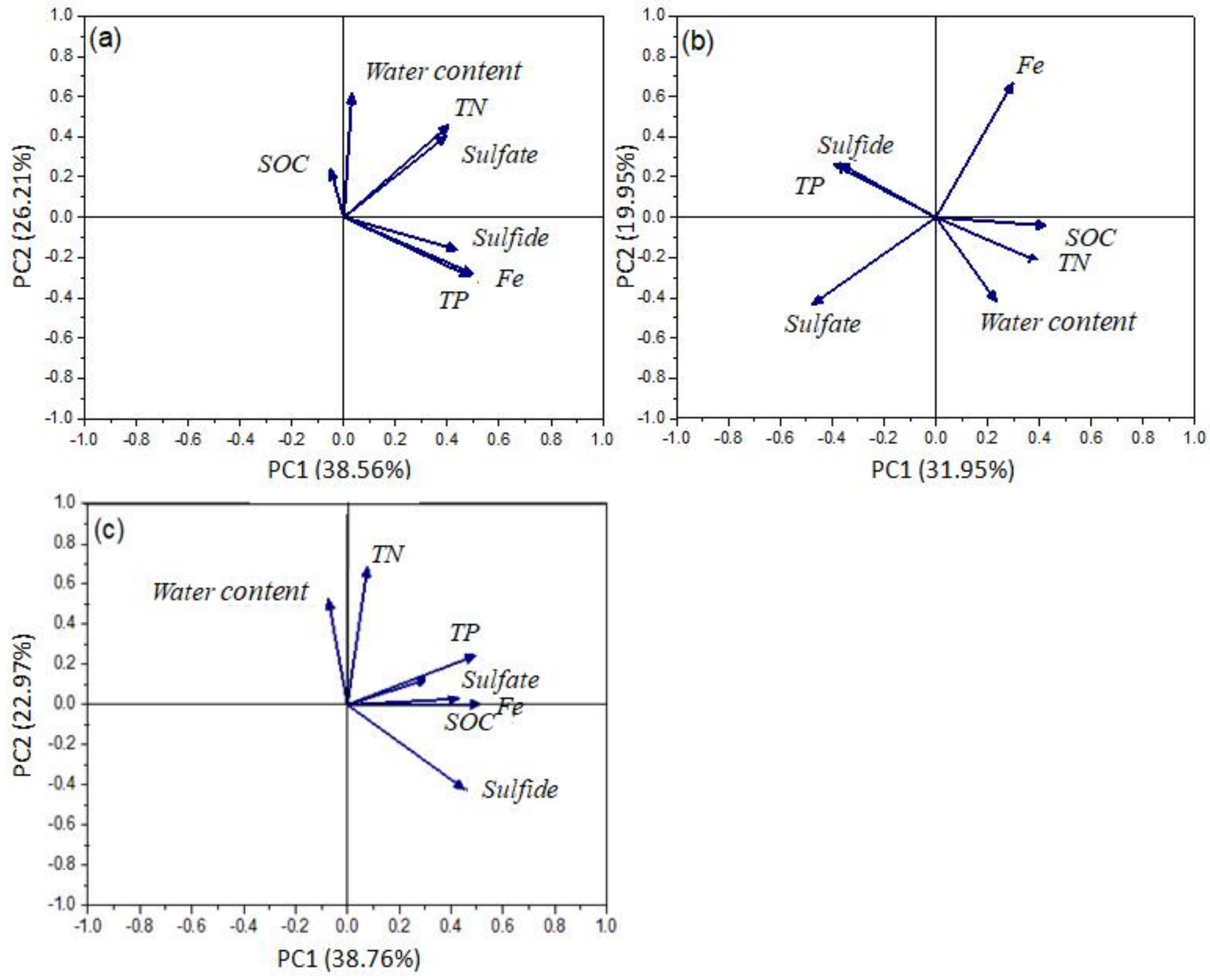

Figure 3

Correlation of soil sulfate, sulfide and environmental factors in (a) mudflats, (b) S. mariqueter, (c) S. alterniflora by PCA 


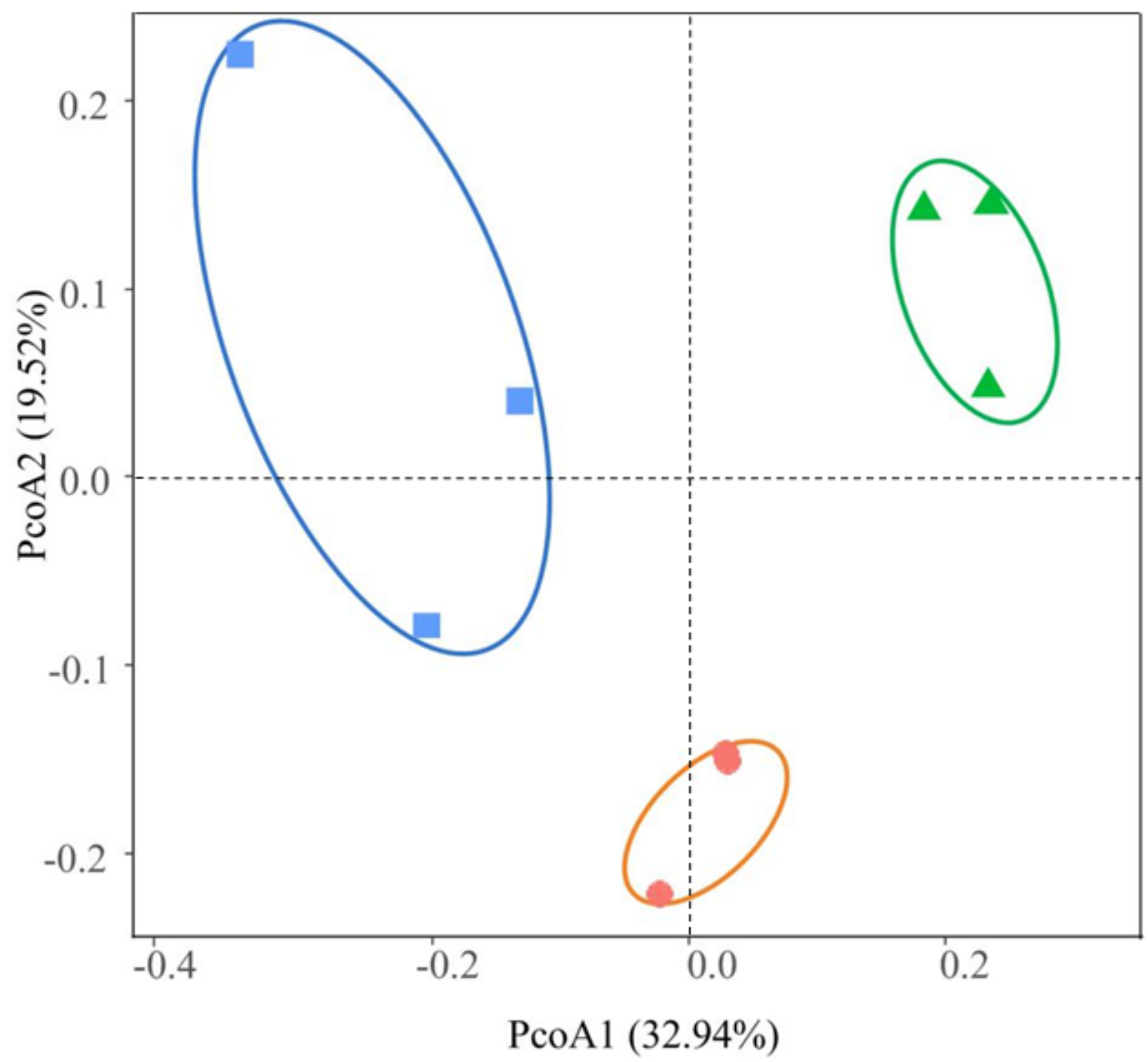

$\cdot \mathrm{MF}$
$* \mathrm{SA}$
$-\mathrm{SM}$

\section{Figure 4}

Principal coordinates analysis (PcoA) based on the Bray-Curtis distance matrix of microbial populations in the soils collected from different sites (Mudflat (MF); S. mariqueter (SM); S. alterniflora (SA)) 


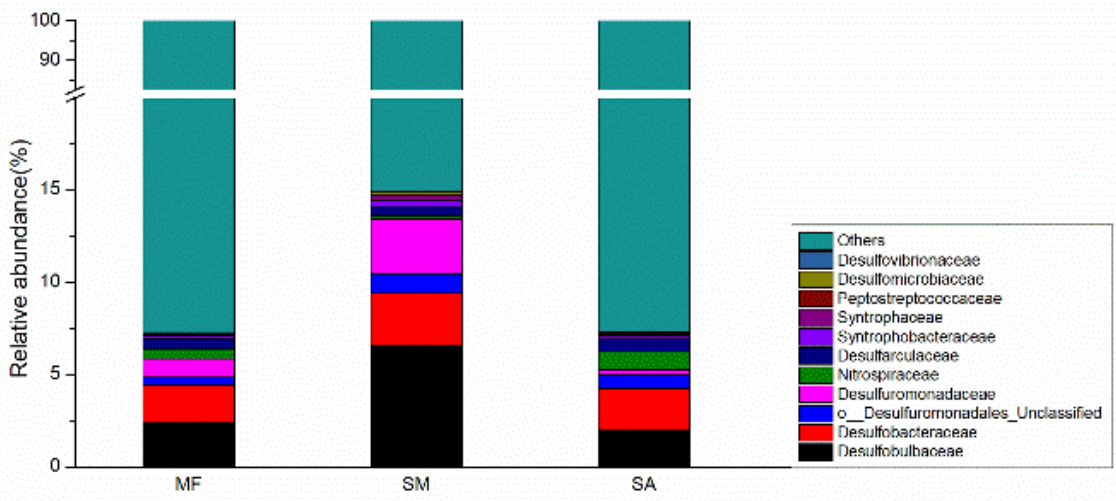

(A)

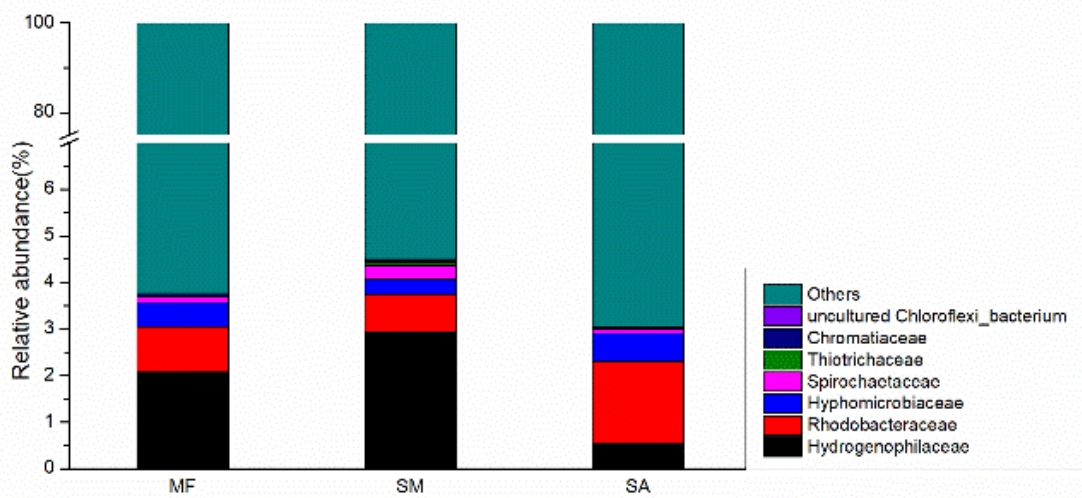

(B)

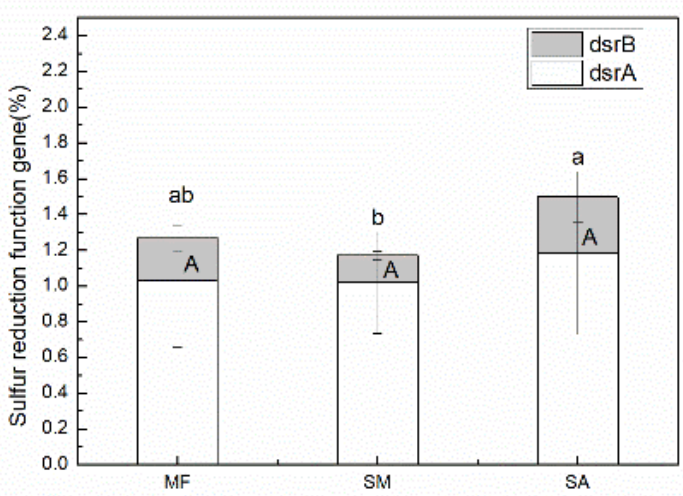

(C)

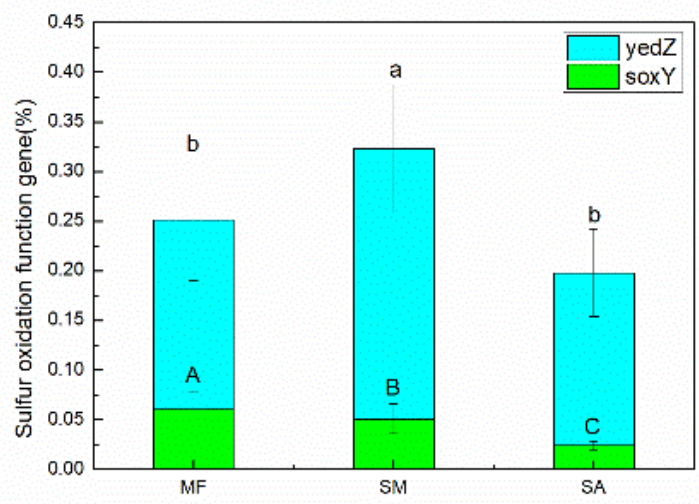

(D)

\section{Figure 5}

The relative abundance of sulfur-reducing bacteria (A) and sulfur-oxidizing bacteria (B) at the family level in different vegetation types (Mudflat (MF); S. mariqueter (SM); S. alterniflora (SA)). The relative abundance of sulfur-oxidizing (C) and sulfur-reducing (D) functional genes in different vegetation types based on the results of the QMEC test. Different letters indicate significant differences $(P<0.05)$ between means of different stands 

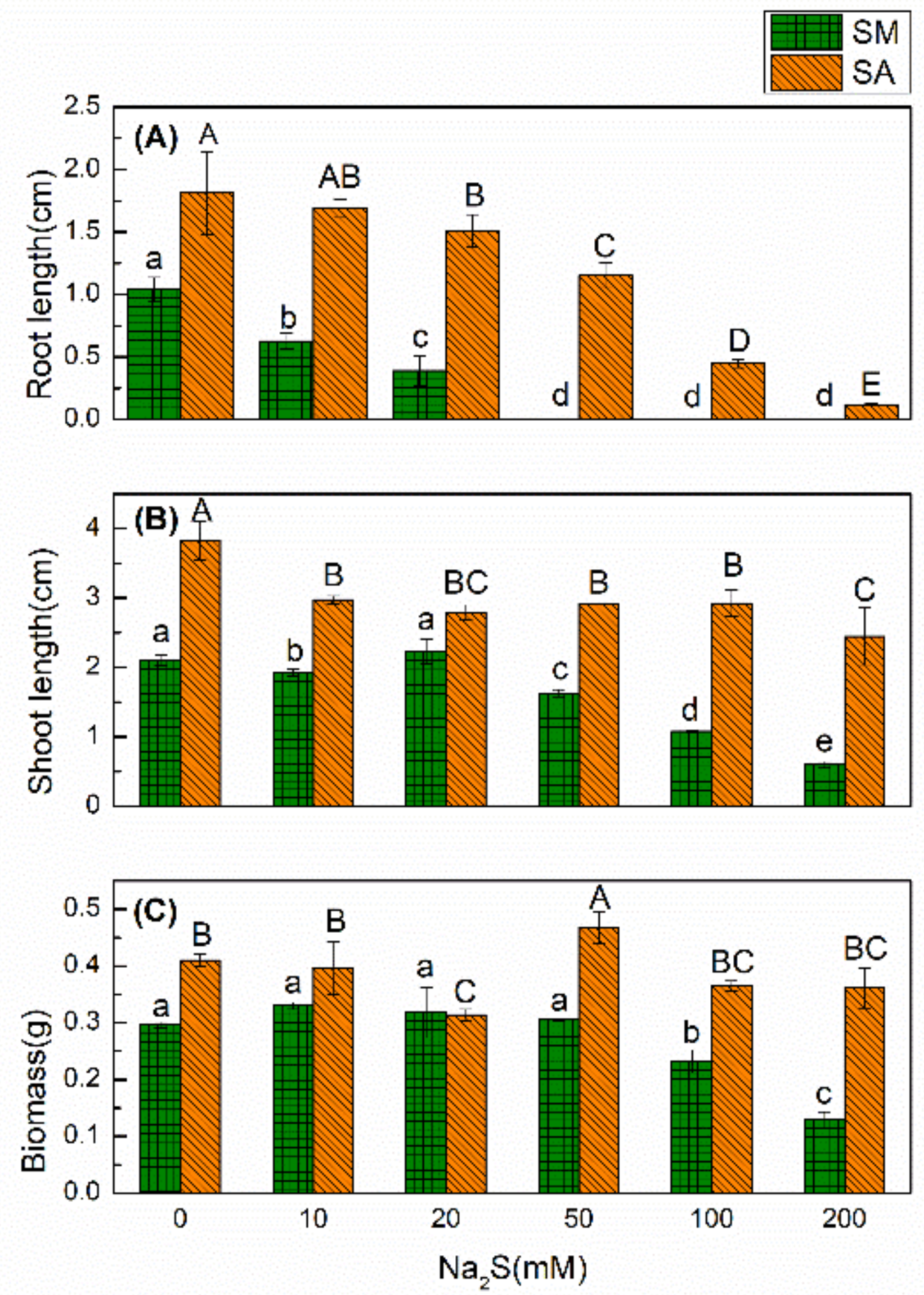

Figure 6

(A) Root lengths, (B)shoot lengths, and (C)biomass of seed germination of S. alterniflora (SA) and S. mariqueter (SM) under different concentrations of Na2S. Lowercase letters and uppercase letters respectively indicate significant differences $(P<0.05)$ of $S$. alterniflora and $S$. mariqueter between means of different stands 